\title{
Fábula sobre los videojuegos y la televisión
}

\section{Irene Trousselle}

Se acercaba el fin del año escolar, y Conejo y sus amigos hacían planes para el verano. Conejo y sus amigos, vivían en un pueblo que estaba a la par de un hermoso lago donde los animales podían ir a nadar, ir de pesca y acampar. El pueblo también tenía zonas para ir de excursión y para pasear en bicicleta.

Conejo tenía dos hermanas, un hermano y varios amigos en la escuela, pero su mejor amigo era Pato. Conejo y sus amigos hicieron planes para las vacaciones de verano y con ansiedad esperaban empezar sus aventuras.

Pero Conejo tenía una debilidad: le gustaba jugar videojuegos y ver televisión, y esto a veces le causaba problemas con sus padres, porque cuando jugaba sus videojuegos y veía televisión, no hacía sus tareas escolares ni limpiaba su recámara.

_ ¡Por fin llegaron las vacaciones de verano! - dijo Conejo a sus amigos.

- Podemos ir a nadar, pescar, jugar futbol y muchas cosas más - contestó Pato.

Al pasar unos días, Pato y Ardilla fueron a buscar a Conejo para invitarlo a jugar, pero Conejo les dijo:

- Hoy no, tal vez mañana, estoy en el octavo nivel de mi videojuego.

Pato y Ardilla se miraron el uno al otro y se fueron. El siguiente fin de semana la familia de Conejo se preparó para ir de paseo en bicicleta. Conejo no quiso ir y les dijo:

- Mi programa favorito está en la televisión. Hoy no, tal vez mañana.

Conejo contestó lo mismo a varias invitaciones que le hicieron sus amigos y familia durante muchas semanas.

Un día Conejo vio a sus amigos en la tienda y les pregunto qué hacían. Le contestaron que iban de excursión a las cuevas de las que el maestro de ciencias les había platicado. Conejo les dijo que él también quería ir pero Pato le contestó que lo sentía, pero no había cupo en la camioneta. Ardilla le dijo:

- Conejo, hoy no, tal vez mañana-y los amigos de Conejo se despidieron. Cuando llegó a su casa, su familia estaba haciendo planes para ir al cine a ver una película de superhéroes. Éstas eran las películas favoritas de Conejo, y le preguntó a su papá a qué hora era la película para él estar listo. Su padre le contestó:

-Hijo no pensé que quisieras ir. Tienes semanas que no quieres hacer nada más que jugar videojuegos y ver televisión, y los boletos están agotados. Lo siento mucho Conejo, hoy no, tal vez mañana.

Conejo estaba triste, sentado enfrente de su casa, cuando Don Búho lo vio y le preguntó qué le pasaba. 
Conejo le platicó sobre todo lo sucedido y Don Búho le dijo:

- Conejo, tú hiciste prioridad de tus videojuegos y televisión, así que pide disculpas a tus amigos y sobre todo a tu familia, porque los videojuegos y la televisión nunca podrán remplazar a tu familia y amigos. 